\title{
Evaluation of Effectiveness of Covalently Immobilized $\alpha$ - Amylase and Lipase in Cleaning of Historical Textiles
}

\author{
Sawsan S. Darwish 1 ${ }^{10}$, Mohamed E. Hassan ${ }^{2, *}$, Harby E. Ahmed ${ }^{1}$ (D), Mustafa Abo El Fadl ${ }^{3}$, Mohamed \\ B. El Bhery 4
}

1 Conservation Department, Faculty of Archaeology, Cairo University, Giza, Egypt; sawsansd@hotmail.com (S.S.D.); harbyezzeldeen@cu.edu.eg (H.E.A.);

2 Center of Excellence, Encapsulation and Nano Biotechnology Group, Chemistry of Natural and Microbial Products Department, National Research Center, El Behouth Street, Cairo 12622, Egypt; mohassan81@ gmail.com (M.E.H.);

3 Supreme Council of Antiquities, Egypt; Mustafaaboelfadl@yahoo.om (M.A.E.F.);

4 Restoration of Egyptian antiquities Department, the Egyptian Ministry of Tourism and Antiquities. Egypt; Elbherymohamed30@gmail.com (M.B.E.);

* Correspondence: mohassan81@gmail.com;

Scopus Author ID 56082999400

Received: 22.08.2020; Revised: 17.09.2020; Accepted: 19.09.2020; Published: 23.09.2020

\begin{abstract}
Historical textiles are exposed to damage as a result of many factors, such as climate changes. Cleaning of these historical textiles is very important. It can be done using the immobilization technology of enzymes. For this purpose, amylase and lipase were covalently immobilized on the surface of chemically activated alginate/carrageenan gel beads. Preparation, activation, and immobilization steps were characterized by FT-IR and TGA. Optimization of loading units and time for two enzymes were done. From the obtained results, we found that the optimum units and time for amylase are $25 \mathrm{U}$ and $4 \mathrm{hrs}$, respectively. And the optimum units and time for lipase are $15 \mathrm{U}$ and $3 \mathrm{hrs}$, respectively. From the obtained results, immobilized $\alpha$-Amylase and lipase can be used in the cleaning and restoration of historical textiles.
\end{abstract}

Keywords: enzyme immobilization; $\alpha$-amylases; lipase; thermal gravimetric analysis; historical textiles.

(C) 2020 by the authors. This article is an open-access article distributed under the terms and conditions of the Creative Commons Attribution (CC BY) license (https://creativecommons.org/licenses/by/4.0/).

\section{Introduction}

Enzymes utilization has been increased rapidly in all countries in the world; the worldwide usage of enzymes is about $€ 1.7$ billion [1]. Because of the high price of commercial carriers that are used in enzymes immobilization, there is a persistent need to find a new cheap one. Alginate and carrageenan are two polymers that are found naturally and also cheap. Moreover, they can be used in many industries, such as food, pharmacy, textile, and also nutrition [2].

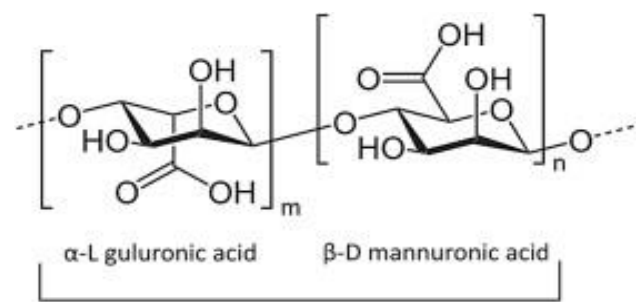

Figure 1. Alginic acid. 
Alginate is a polysaccharide composed of blocks of b-D mannuronic and a-L-guluronic subunits residues, as in figure 1, alginate can be cross-linked (hydrogel) in the presence of $\mathrm{CaCl}_{2}$, multivalent cation, to form an ionic network (alginate gel beads) [3]. On the other hand, $\mathrm{k}$-carrageenan is a natural biopolymer that is presented naturally in algae. This polyanion polymer contains a sulfate group (figure 2). This polymer can be cross-linked in the presence of $\mathrm{KCl}$ to form rigid gel beads [4].

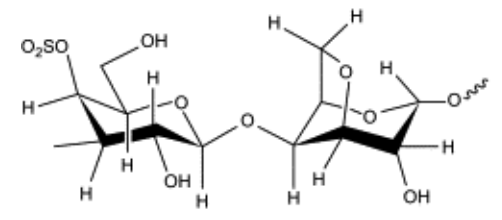

Figure 2. k-carrageenan.

Hence, the interaction between alginate and carrageenan polymers can improve the stability and activity of newly formed gel beads. Enzymes have great potential in present days as a catalyst in many biotechnological applications such as pharmaceutical, fermentation, food, paper, and textile industries [5] these enzymes such as amylase and lipase. $\alpha$-Amylases, extracellular enzymes, are one of the most important and popular enzymes that cleave 1, 4- $\alpha$ D-glucosidic linkages. It has a particular interest as it is inexpensive and commercially available. Amylases can hydrolysis starch producing glucose units and also known as starchliquefying amylase [6].

The other one is lipase, which is a very interesting one due to its ability to catalyze many reactions. These enzymes also can be used in industrial and biotechnological applications in fat and oil hydrolysis as well as hydrolyzing several insoluble triacylglycerols [7].

Aiming their biotechnological and industrial applications, amylase and lipase should be stable enough and can be used for several times that reduce the final product cost. This can be done by immobilization technologies that improve stability and catalytic properties leading to higher catalyst efficiency [8].

There are many technologies that are used in the immobilization of cells or enzymes, these technologies such as entrapment, adsorption, covalent, encapsulation, and cross-linking immobilization. From these methods, covalent immobilization has a great advantage that prevents enzyme leakage because of the strong bond that formed between the support and enzyme. So that the immobilization via covalent bond is preferred widely in industry as it reduces product cost by using immobilized enzymes many times [9].

However, alginate and carrageenan are devoid of functional groups active in their surface for immobilization technique. The incorporation of a new active function group $(\mathrm{C}=\mathrm{O})$ group on their surface can be done [10].

Historical textiles are very important; they are exposed to a lot of confrontations, such as temperature, air pollution, humidity, light, and non-standard storage methods [11]. All these factors can cause decay and damage in both fibers and dyes that result in weakness in dyes and fibers, loss parts [12]. Also, one of the most important factors is the pollution of oils and starch that damage the textile fibers [13].

In this work, formulation of alginate/carrageenan beads and activation using polyethyleneimine (PEI) followed by glutaraldehyde (GA) for covalent immobilization of $\alpha-$ Amylases and lipase to be used in the conservation of historical textiles in Egypt. 


\subsection{Description of the object.}

It is a coarse Cotton mantle; the age of the mantle is more than 750 years old, as mentioned in Almakrezy's book Alsayed Ahmad Bn Ali Ibraheem Albadawy, nicknamed "Alsayed AL Badawi" (figure 3). This mantle was found in the special room of Alsayed Albadawy and with an opening on the front with the length of the mantle [14].

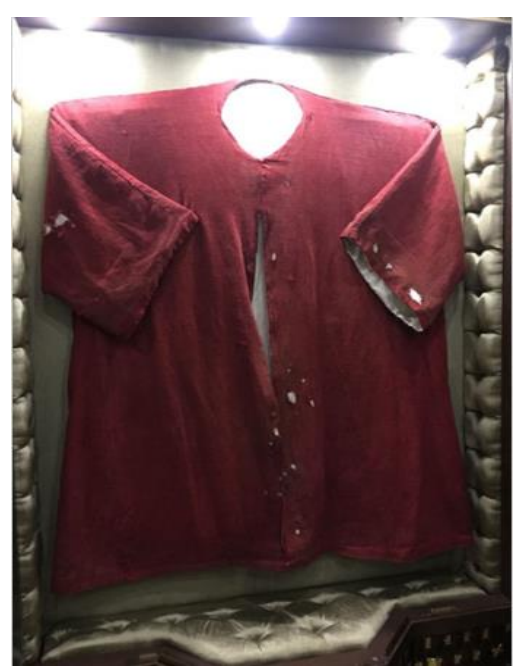

Figure 3. The historical tunic that consists of three different textiles layers.

\section{Materials and Methods}

\subsection{Materials.}

$\kappa$-carrageenan and alginate sodium salt were purchased from Fluka, Switzerland. Glutaraldehyde solution (GA) and Polyethyleneimine (PEI) were purchased from SigmaAldrich, Germany. All other reagents were of analytical grade.

\subsection{Methods.}

2.2.1. determination of enzyme activity.

\subsubsection{Amylase activity.}

Determination of $\alpha$-amylase enzyme activity was done by incubation of $0.5 \mathrm{ml}$ of soluble starch $(1 \%)$ dissolved in $0.1 \mathrm{M}$ phosphate buffer at $\mathrm{pH} 7.0$ and the same volume of the enzyme $(0.5 \mathrm{ml})$ at $40{ }^{\circ} \mathrm{C}$ for $0.5 \mathrm{hr}$. Dinitrosalicylic acid (DNS) was used to stop the reaction and determination of librating sugar at $540 \mathrm{~nm}$. One unit of amylase activity (U) is defined as the amount of enzyme used to liberate $1 \mu$ mole of reducing sugar under assay conditions $[15$, 16].

\subsubsection{Lipases activity.}

Lipase catalytic activity was determined by enzymatic hydrolysis of p-NPA by measuring the increment of p-nitrophenol spectrophotometrically at $400 \mathrm{~nm}$. Lipase enzyme was added to $0.2 \mathrm{mM}$ p-NPA $(3 \mathrm{ml})$ in phosphate buffer $\mathrm{pH} 7.2$ in quartz cuvette for $5 \mathrm{~min}$. One lipase unit (U) was defined as the amount of lipase that was used to release $1 \mu \mathrm{mol}$ of product at assay conditions $[17,18]$. 
2.2.2. Formulation and grafting of alginate/carrageenan gel beads.

Alginate/carrageenan (Alg.Carr.) gel beads were formulated by dissolving alginate sodium salt and $\kappa$-carrageenan separately. After completely desolvation, the two solvents were mixed to reach final concentrations alginate $(2 \% \mathrm{w} / \mathrm{v})$ and $\mathrm{k}$-carrageenan $(1 \% \mathrm{w} / \mathrm{v})$. Alg.Carr. The solution was then dropped in $\mathrm{CaCl}_{2}$ as a hardening solution by using a $100 \mu \mathrm{m}$ nozzle of the Innotech Encapsulator, that shown in figure 4. After soaking in a hardening solution for 6 hrs, beads become ready for further modification and ready for the immobilization process [19].

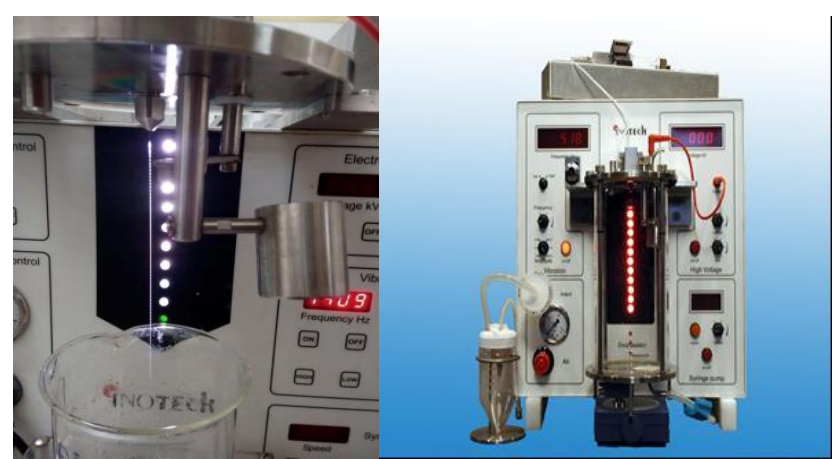

Figure 4. Innotech encapsulator for beads preparation.

\subsubsection{Activation of Alg.Carr. gel beads.}

Alg.Carr. gel beads were be activated by soaking in $1 \%$ PEI at $8.4 \mathrm{pH}$ for only $10 \mathrm{~min}$. Then the gel beads were washed well to remove unreacted PEI. Aminated Alg.Carr gel beads were then activated by soaking in glutaraldehyde solution at $5 \%$ for $30 \mathrm{~min}$ and $\mathrm{pH}$ of 4 at room temperature. Then the gel beads were washed well to remove unreacted glutaraldehyde [20]. The activated Alg.Carr. beads were ready for the covalent immobilization steps as in scheme 1.

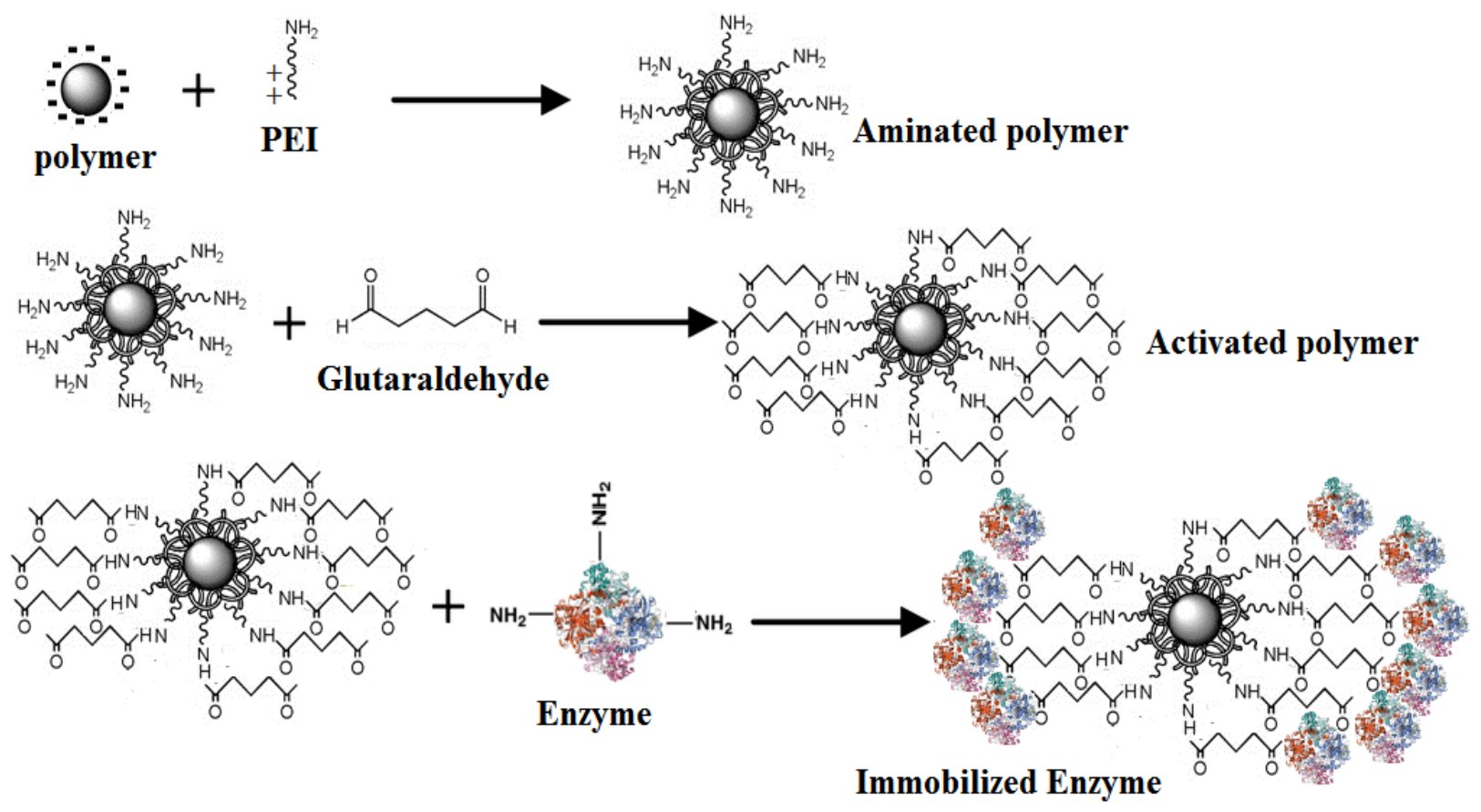

Scheme 1. Mechanism of alginate/carrageenan gel beads activation and enzyme immobilization. 


\subsubsection{Enzyme immobilization.}

For the immobilization of enzymes, the two enzymes were incubated separately with the activated alginate/carrageenan gel beads at $4{ }^{\circ} \mathrm{C}$ overnight. After this period, the gel beads were to be ready for the next step by washing well with buffer [20, 21].

2.2.5. Maximum loading units and optimum time of immobilization determination.

\subsubsection{Determination of maximum loading units.}

The activated Alg.Carr gel beads were soaked in different concentrations of the enzyme (amylase and lipase separately) ranging from $2.5 \mathrm{U} / \mathrm{gm}$ beads till $35 \mathrm{U} / \mathrm{gm}$ beads, and the result gives the sufficient concentration that needed to react with aldehyde groups ( active groups) found on the surface of gel beads.

\subsubsection{Determination of optimum reaction time.}

To determine the optimum reaction time needed to give full hydrolysis of starch and oils found on the textile. One gram containing $15 \mathrm{U}$ of enzymes reacted with $3 \mathrm{~cm}^{2}$ of cloth for different times ranging from $0.5-7 \mathrm{hrs}$.

\subsubsection{Fourier Transform Infrared (FT-IR).}

The infrared spectra of all formulations in Scheme 1 were determined by using FT-IR (FTIR-8300, Shimadzu, Japan) from 4000 to $400 \mathrm{~cm}^{-1}$ at ambient temperature.

2.2.7. Thermal gravimetric analysis.

The thermal behavior of the formulated gel beads at every step (alginate/carrageenan, alginate/carrageenan + PEI, alginate/carrageenan + PEI + GA, and alginate/carrageenan + PEI + GA + Enz.) was characterized by the DSC (SDT 600, TA Instruments, USA). A typical sample of gel beads was heated from 50 to $300{ }^{\circ} \mathrm{C}$ at a heating rate of $10{ }^{\circ} \mathrm{C} / \mathrm{min}$, under a constant nitrogen flow rate of $100 \mathrm{ml} / \mathrm{min}$.

\section{Results and Discussion}

\subsection{Results.}

3.1.1. Formulation and grafting of Alg.Carr. beads.

For alginate/carrageenan beads preparation, it was found that the optimal concentration of alginate was $2 \%$ and carrageenan $1 \%$, and the hardening solution as calcium chloride in a concentration of $1 \%$ for about 6 hours; these beads formed by using a $100 \mu \mathrm{m}$ nozzle of encapsulator.

\subsubsection{Activation of gel beads.}

The prepared gel beads were activated after complete hardening by soaking in $1 \%$ PEI solution for $10 \mathrm{~min}$. At an optimum $\mathrm{pH}$ of 8.4. After that, it reacted with glutaraldehyde to introduce a new aldehyde group on the gel beads by using $5 \%$ GA for only $30 \mathrm{~min}$ at room temperature. 


\subsubsection{Amylase.}

\subsubsection{Determination of maximum loading units.}

With the increasing of loading units, the immobilized enzyme found on gel beads increased. As in Figure 5, the maximum immobilized enzyme on the Alg.Carr beads were of $25 \mathrm{U} \mathrm{g}^{-1}$ gel beads.

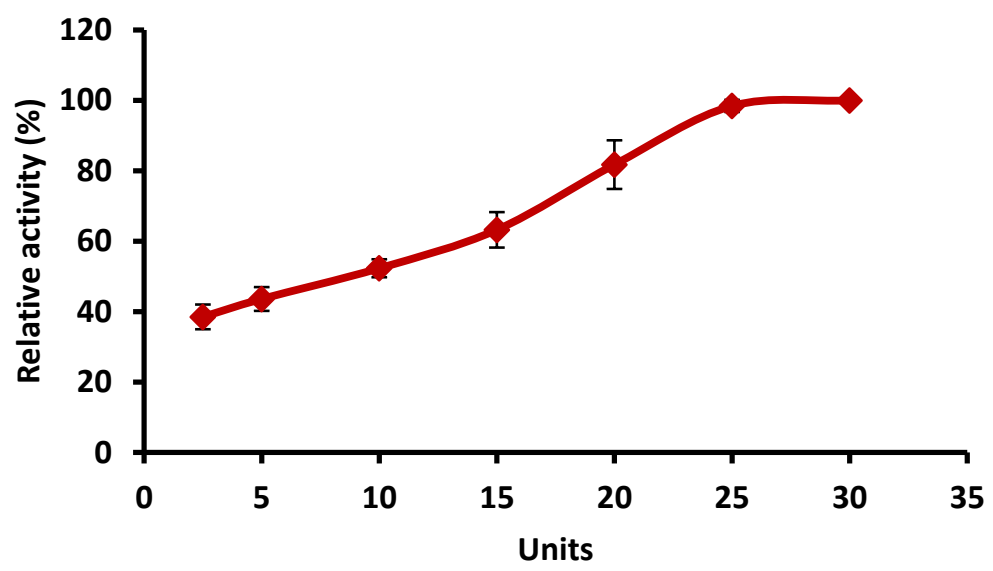

Figure 5. Optimum loading units of $\alpha$-amylase that are immobilized on the surface of gel beads.

\subsubsection{Optimization of reaction time.}

Time optimization of full hydrolysis of starch was shown in figure 6 , and immobilized amylase activity increased as the reaction time increment. As in the figure, the optimum reaction time was $4 \mathrm{hrs}$.

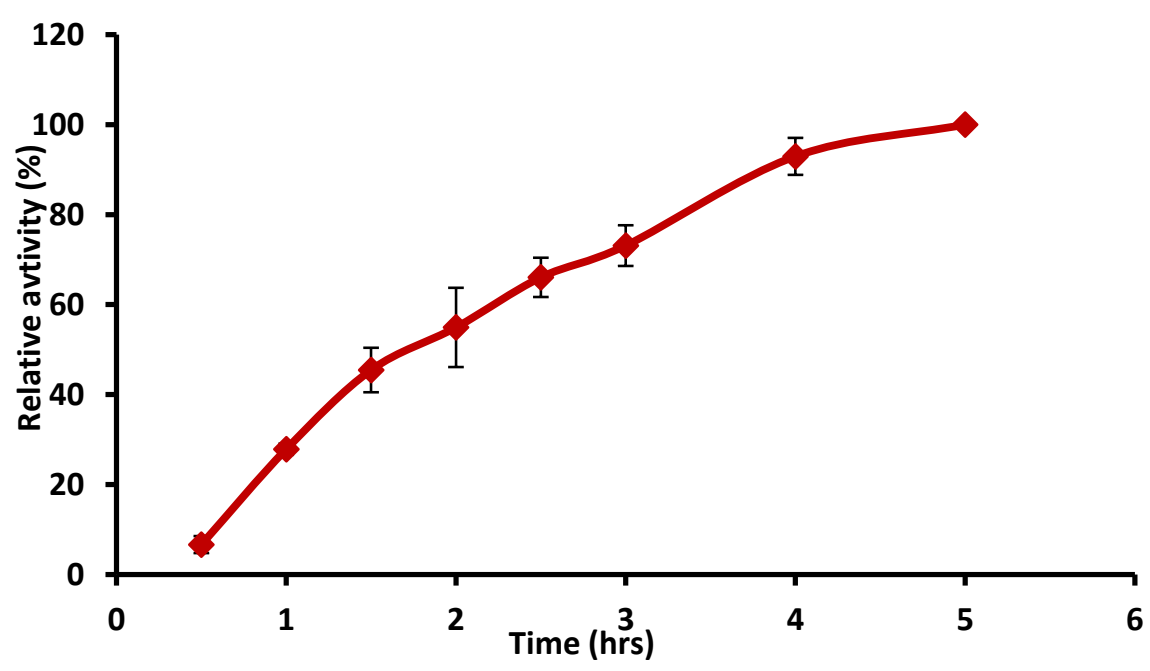

Figure 6. The optimum time for full starch hydrolysis.

3.1.4. Lipase.

3.1.4.1. Determination of maximum loading units.

The immobilized lipase enzyme found on gel beads increased with the increasing of loading units, As in Figure 7, there is a gradual increase in activity till $15 \mathrm{U}$, and after that, there are no more enzymes units increased on the gel beads. 


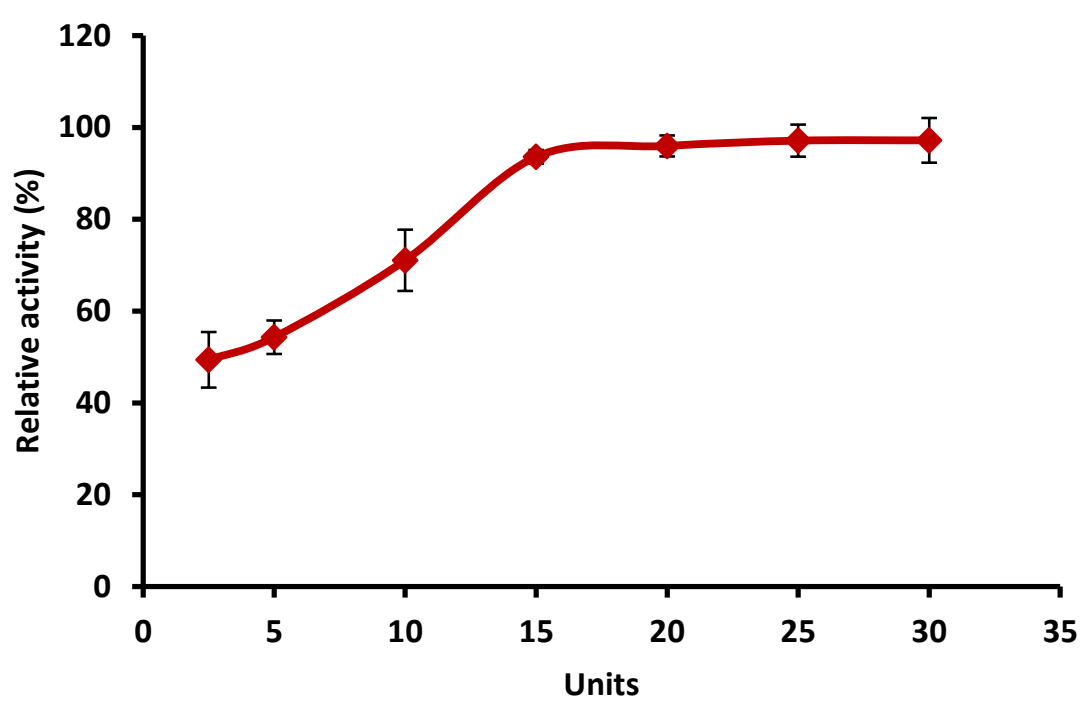

Figure 7. Optimum loading units of immobilized lipase on the gel beads.

\subsubsection{Optimization of reaction time.}

Time optimization of full hydrolysis of oil was shown in figure 8; immobilized lipase increased as reaction time increment. As in the figure, the optimum reaction time was $3 \mathrm{hrs}$.

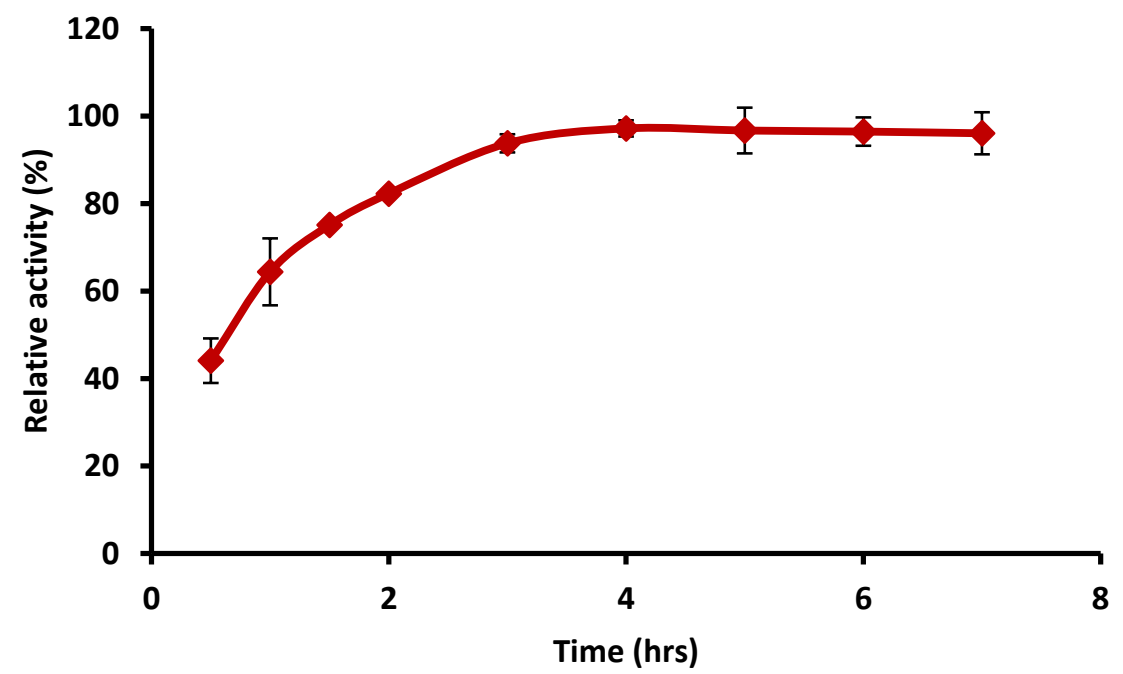

Figure 8. The optimum time for full oil hydrolysis.

\subsection{FT-IR spectra of formulated gel beads.}

As in figure 9, the FT-IR spectra of formulated gel beads in different steps showed distinctive beaks. Curve A represented the blank beads (Alg.Carr). In curve B, there is a new beak at 3429 that corresponding to amine groups $\left(\mathrm{NH}_{2}\right)$. Curve $\mathrm{C}$ is the representative one for activated gel beads. In this one, there are two distinctive beaks. One of them is at 1717 that refers to the free aldehyde group, and the other one at 1660 that refers to an amide bond. Moreover, immobilized gel beads that represented by curve D has a broader beak at 3457 that refers to increment in amine groups concentration. These results were in agreement with the results obtained by other published results [22, 23]. 


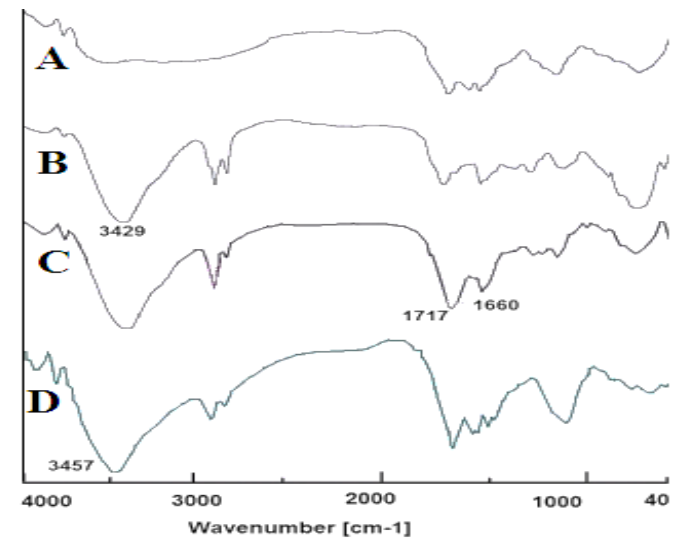

Figure 9. FT-IR spectra of alginate/carrageenan gel beads (A), aminated beads (B), activated beads (C), and immobilized one (D).

\subsection{Thermal gravimetric analysis.}

The TGA thermogram of alginate/carrageenan, alginate/carrageenan/PEI, alginate/carrageenan /PEI/GA, and alginate/carrageenan /PEI/GA/Enz. Were shown in Fig. 10 and in Table 1. A piecemeal improvement in TGA was observed in different steps of formulations. The TGA of alginate/carrageenan was $169{ }^{\circ} \mathrm{C}$ while aminated alginate/carrageenan was $196^{\circ} \mathrm{C}$, and TGA for activated alginate/carrageenan was $222^{\circ} \mathrm{C}$. At the same time, it was $319^{\circ} \mathrm{C}$ for enzyme immobilization one. The results in (Table 1) for $\mathrm{TGA}_{50 \%}$ at which $50 \%$ of the polymer (alginate/carrageenan) has been degraded showed that the improvements in the TG might be due to the formation of a stronger cross-link of the beads due to Schiff's base formation between the free PE's amino groups and GA. Danial et al., 2010 reported that when calcium alginate was treated with PEI and followed by GA [24], an obvious improvement in their TGA50\% was observed by Abd El Aty et al., 2017 [25].

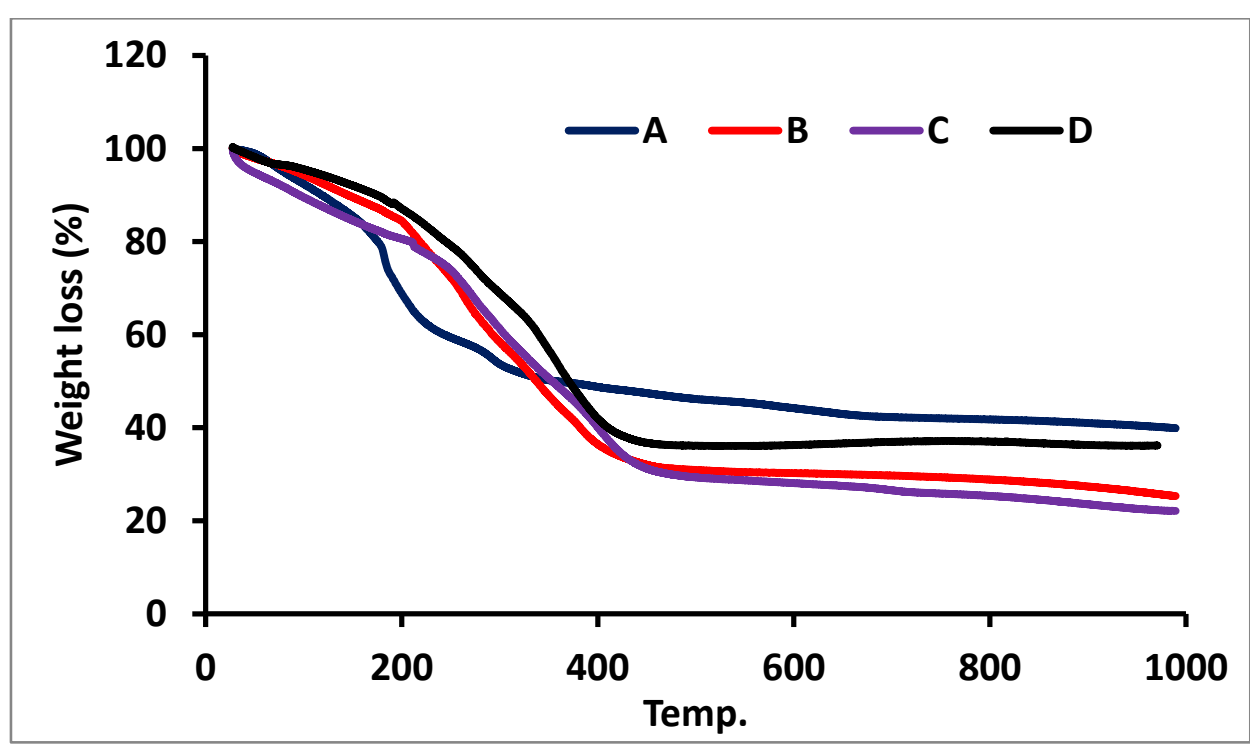

Figure 10. TGA thermogram of all formulations A (alginate/carrageenan), B (alginate/carrageenan $+\mathrm{PE}), \mathrm{C}$ (alginate/carrageenan $+\mathrm{PE}+\mathrm{GA})$, and D (alginate/carrageenan + PE + GA + Enz.).

Table 1. Thermogravimetric analysis and $\mathrm{T}_{50 \%}$ data of preparation, activation, and immobilization steps.

\begin{tabular}{l|l|l} 
Step & TGA & $\mathbf{T}_{\mathbf{5 0} \%}$ \\
\hline Alg.Carr. & 169 & 331 \\
\hline Alg.Carr.+ PEI & 196 & 339 \\
\hline Alg.Carr.+ PEI + GA & 222 & 355 \\
\hline Alg.Carr.+ PEI + GA + Enz. & 319 & 373
\end{tabular}




\subsection{Discussion.}

Formation of Alg.Carr. gel beads using a low concentration of calcium chloride (1\%) results in an ionic network between two anions Alg. (-COO-) and Carr. (-OSO-) and cation $\left(\mathrm{CaCl}_{2}\right)$. This ionic network produces porous and rough Alg.Carr gel beads. These new characters allow for the large amount of amylase and lipase enzymes immobilized on the gel beads surface and in its pores. For this low concentration of calcium ions, the soaking time increased to be 6hrs. These results were in agreement with that found by Elnashar et al. 2014 [19]. Using of low concentration of PEI (1\%) for only $10 \mathrm{~min}$ implied that more amine groups were found on the surface of Alg.Carr gel beads. Fewer protonated PEI ( $\mathrm{pH}$ 8.42) is responsible for ionic interaction between positively charged PEI and negatively charged Alg.Carr. [22]. To discuss the loading effect of amylase, there are several possible effects that come from enzyme crowding. One of these effects is that this enzyme crowding may reduce enzyme movements and mobilities as the enzyme chain will crash against the surrounding protein. On the other hand, the hydrophobic pockets of the enzyme, during enzyme incubation at high temperature, maybe on the reversible of outside. All of this may be to decrease the stability of the enzyme [26]. The optimum time of amylase was found that the enzyme needs only 4 hours to reach complete hydrolysis of starch found on the surface of the textile piece. The full hydrolysis of starch increases gradually up to 4 hours; this may be due to that the immobilization process elongates the time needed for the interaction between immobilized enzyme and substrate [27, 28]. No doubt that the most important factor of the immobilized enzyme is its catalytic function. In the case of lipase enzyme, it was found that the maximum enzyme units laded on the surface of gel beads were only $15 \mathrm{U}$, while Zhu et al., 2013 said that it was about $19.9 \mathrm{U} / \mathrm{g}$ when he used immobilized lipase on esterified loofah sponge [29]. The optimum time of full hydrolysis of oil was 3 hours, while Kenthorai et al., 2009 found that the optimum time of full hydrolysis of palm oil was 72 hours when he used encapsulated lipase in carrageenan for biodiesel production [30] and The co-immobilized lipase on polyurethane foam (PUF) can be used effectively to hydrolyze coconut oil to Free Fatty Acid (FFA) in 20 hrs as reported by Moentamaria [31]. From FT-IR and TGA characterization tools, it was proved that gel amination, gel activation, and enzyme immobilization takes place successfully. This result was in agreement with other published results [22, 23].

\section{Conclusions}

Alginate/carrageenan complex was used for covalent immobilization of $\alpha$-amylase and lipase and used in cleaning and restoration of historical textiles. The optimum loading units and time for two enzymes were determined. Evaluation of gel beads preparation, activation, and enzyme immobilization were done using FT-IR and TGA instruments.

\section{Funding}

This research received no external funding.

\section{Acknowledgments}

This research has no acknowledgment. 


\section{Conflicts of Interest}

\section{The authors declare no conflict of interest.}

\section{References}

1. Wahba, M.I.; Hassan, M.E. Agar-carrageenan hydrogel blend as a carrier for the covalent immobilization of $\beta$-D-galactosidase. Macromol Res 2017, 25, 913-923, https://doi.org/10.1007/s13233-017-5123-8.

2. Reis, C.L.B.; Sousa, E.Y.A.; Serpa, J.F.; Oliveira, R.C.; Santos, J.C.S. Design of immobilized enzyme biocatalysts: Drawbacks and Opportunities. Química Nova 2019, 42, 768-783, http://dx.doi.org/10.21577/0100-4042.20170381.

3. Tianxin, M.; Junqing, W.; Yun, Z.; Gang, L.; Xiaoyuan, C. Polysaccharide-Based Controlled Release Systems for Therapeutics Delivery and Tissue Engineering: From Bench to Bedside. Adv. Sci. 2018, 5, https://doi.org/10.1002/advs.201700513.

4. Hassan, M.E.; Jun, B.; Dou, D.Q. Biopolymers; Definition, Classification and Applications, Egyptian Journal of Chemistry 2019, 62, 1725-1737, https://doi.org/10.21608/ejchem.2019.6967.1580.

5. Jordan, C.; Ahmed, E.I.; Cerasela, Z.D. Industrial Applications of Enzymes: Recent Advances, Techniques, and Outlooks. Catalysts 2018, 8, https://doi.org/10.3390/catal8060238.

6. Pandey, A.; Nigam, P.; Soccol, C.; Soccol, V.; Singh, D.; Mohan, R. Advances in microbial amylases. Biotechnol. Appl. Biochem. 2000, 31, 135-152.

7. Shivika, S.; Shamsher, S.K. Organic Solvent Tolerant Lipases and Applications. Scientific World Journal 2014, 2014, https://doi.org/10.1155/2014/625258.

8. Shuang, L.; Xiaofeng, Y.; Shuai, Y.; Muzi, Z.; Xiaoning, W. Technology Prospecting on Enzymes: Application, Marketing and Engineering. Comput Struct Biotechnol J. 2012, 2, https://doi.org/10.5936/csbj.201209017.

9. Hassan, M.E.; Yang, Q.;Xiao, Z. Covalent immobilization of glucoamylase enzyme onto the chemically activated surface of $\kappa$-carrageenan. Bulletin of the National Research Centre 2019, 43, https://doi.org/10.1186/s42269-019-0148-0.

10. Ali, K.A.; Hassan, M.E.; Elnashar, M.M. Development of functionalized carrageenan, chitosan and alginate as polymeric chelating ligands for water softening. Int. J. Environ. Sci. Technol. 2017, 14, 2009-2014, https://doi.org/10.1007/s13762-017-1298-y.

11. Ahmed, H.E.A new approach to the conservation of metallic embroidery threads in historic textile object from private collections. Int J Conservation Sci 2014, 5, 21-34.

12. Aslanidou, D.; Tsioptsias, C.; Panayiotou, C. A novel approach for textile cleaning based on supercritical $\mathrm{CO}_{2}$ and pickering emulsions.J Supercrit Fluids 2013, 76, 83-93, https://doi.org/10.1016/j.supflu.2013.02.005.

13. Barlow, A. Conservation of an early nineteenth-century blockprinted dress: techniques and historical importance.Fashion Institute of Technology, New York, USA 2016

14. Harby, E.A.; Mustafa, A.F.; Mohammed, K.; Maisa, M.An Extensive Study of Examination, Restoration, and Display of a Rare Historical Costumes, Practical Application. J Textile Eng \& Fashion Tech. 2018, 1, http://dx.doi.org/10.33552/JTSFT.2018.01.000506.

15. Samia, A.A.; Mohamed, A.A.; Gamal, M.E.; Atef, M.I.; Aliaa, R.E.; Sherien, M.A.; Mohamed, E.H. Catalytic, kinetic and thermal properties of free and immobilized Bacillus subtilis-MK1 $\alpha$-amylase on Chitosan-magnetic nanoparticles. Biotechnology Reports https://doi.org/10.1016/j.btre.2020.e00443.

16. Jain, A.; Jain, R.; Jain, S. Determination of Salivary Amylase Activity. In: Basic Techniques in Biochemistry, Microbiology and Molecular Biology. Springer Protocols Handbooks. Humana, New York, NY. 2020, https://doi.org/10.1007/978-1-4939-9861-6_52.

17. Wang, J.Y.; Ma, C.L.; Bao, Y.M.; Xu, P.S. Lipase entrapment in protamine-induced bio-zirconia particles: characterization and application to the resolution of (R,S)-1-phenylethanol.Enzyme Microb. Technol. 2012, 51, 40-46, https://doi.org/10.1016/j.enzmictec.2012.03.011.

18. Fujiwara, M.; Shiokawa, K.; Yotsuya, K.; Matsumoto, K. Immobilization of lipase from Burkholderia cepacia into calcium carbonate microcapsule and its use for enzymatic reactions in organic and aqueous media. J Mol Catal B Enzym 2014, 109, 94-100, https://doi.org/10.1016/j.molcatb.2014.08.009.

19. Elnashar, M.M.; Wahba, M.I.; Amin, M.A.; Eldiwany, A.I. Application of Plackett-Burman Screening Design to the Modeling of Grafted Alginate-Carrageenan Beads for the Immobilization of Penicillin $\mathrm{G}$ Acylase. J. Appl. Polym. Sci. 2014, https://doi.org/10.1002/APP.40295.

20. Mohy Eldin, S.M.; El Enshasy, H.A.; El Sayed, M.; El Sayed, S.; Haroun, B.; Hassan, E.A. Covalent immobilization of penicillin $\mathrm{G}$ acylase onto chemically activated surface of poly (vinyl chloride) membranes for 6-penicillic acid production from penicillin hydrolysis process I. Optimization of surface modification and its characterization.J Appl Polym Sci 2012, 124, E27-E36, https://doi.org/10.1002/app.35390. 
21. Faten, A.M.; Abeer, A.A.A.; Mohamed, E.H.; Ghada, E.A.A. immobilization of xylanase on modified grafted alginate polyethyleneimine bead based on impact of sodium cation effect. Int J Biol Macromol. 2019, 140, 1284-1295, https://doi.org/10.1016/j.ijbiomac.2019.08.211.

22. Hassan, M.; Ran, X.; Yuan, Y.; Luan, X.; Dou, D.Q. Biotransformation of ginsenoside using covalently immobilized Snailase enzyme onto activated carrageenan gel beads. Bull Mater Sci 2019, 42, https://doi.org/10.1007/s12034-019-1730-7.

23. Naidu, K.; Thennarasu, P.K.; Shankar, K.; Kumar, M.; Ramachandiran, S.; Selvaraj, U.; Kalimuthu, K.; Dinakarkumar, Y.; Muthuvel, A. Formulation of alginate based hydrogel from brown seaweed, Turbinaria conoides for biomedical $\quad$ applications. Heliyon 2019, https://doi.org/10.1016/j.heliyon.2019.e02916

24. Danial, E.N.; Elnashar, M.M.; Awad, G.E. Immobilized inulinase on grafted alginate beads prepared by the one-step and the two-steps methods. Ind Eng Chem Res 2010, 49, 3120-3125, https://doi.org/10.1021/ie100011z.

25. Abd El Aty, A.A.; Mostafa, F.A.; Hassan, M.E.; Hamed, E.R.; Esawy, M.A. Covalent immobilization of Alternaria tenuissima KM651985 laccase and some applied aspects. Biocatalysis and Agricultural Biotechnology 2017, 9, 74-81, http://dx.doi.org/10.1016/j.bcab.2016.12.001.

26. Laura, F.; Sara, G.P.; Nerea, L.; Beatriz, C.G.; Jose, J.V.; Roberto, F. Effect of protein load on stability of immobilized enzymes. Enzyme and Microbial Technology 2017, 98, 18-25, https://doi.org/10.1016/j.enzmictec.2016.12.002.

27. Eman, A.K.; Walaa, A.W.; Shireen, A.A.; Mohamed, E.H.; Amany, L.K.; Mona, A.E. Production, immobilization and thermodynamic studies of free and immobilized Aspergillus awamori amylase. Int J Biol Macromol 2017, 102, 694-703, http://dx.doi.org/doi:10.1016/j.ijbiomac.2017.04.033.

28. Ahmed, N.E.; El Shamy, A.R.; Awad, H.M. Optimization and immobilization of amylase produced by Aspergillus terreus using pomegranate peel waste. Bull Natl Res Cent 2020, 44, 109, https://doi.org/10.1186/s42269-020-00363-3

29. Zhu, J.; Zhang, J.; Lai, Q.; Jiang, B.; Gong, R. Covalent immobilization of lipase onto citric acid esterified loofah sponge. BioResources 2013, 8,3289-3298, https://doi.org/10.15376/biores.8.3.3289-3298.

30. Kenthorai, R.J.; Leong, J.Y.; Eng-Seng, C.; Pogaku, R. Design an immobilized lipase enzyme for biodiesel production. Journal of Renewable and Sustainable Energy 2009, 1, https://doi.org/10.1063/1.3256191.

31. Moentamaria, D.; Muharja, M.; Widjaja, T.; Widjaja, A. A Performance Study of Home-Made CoImmobilized Lipase from Mucor miehei in Polyurethane Foam on The Hydrolysis of Coconut Oil to Fatty Acid. Bulletin of Chemical Reaction Engineering \& Catalysis 2019, 14, 391-403, https://doi.org/10.9767/bcrec.14.2.3848.391-403. 